\title{
Bioaccumulation of Mercury in Marine Algae from Dakar Coast (Senegal) and Galician Rias (Spain)
}

\author{
Birame Ndiaye $^{1, ~ *, ~ M o m a r ~ N d i a y e ~}{ }^{1}$, Benita Perez Cid ${ }^{2}$, Abdoulaye Diop ${ }^{1}$, Ibrahima Diagne ${ }^{1}$, \\ Dame Cisse $^{1}$, Cheikh Tidiane Dione ${ }^{1}$, Maoudo Hane ${ }^{1}$ \\ ${ }^{1}$ Department of Chemistry, Faculty of Science and Technology, Cheikh Anta Diop University of Dakar, Dakar, Senegal \\ ${ }^{2}$ Department of Analytical and Food Chemistry, Faculty of Chemistry, University of Vigo, Vigo, Spain
}

Email address:

biramendiaye85@yahoo.fr (B. Ndiaye)

${ }^{*}$ Corresponding author

\section{To cite this article:}

Birame Ndiaye, Momar Ndiaye, Benita Perez Cid, Abdoulaye Diop, Ibrahima Diagne, Dame Cisse, Cheikh Tidiane Dione, Maoudo Hane. Bioaccumulation of Mercury in Marine Algae from Dakar Coast (Senegal) and Galician Rias (Spain). Science Journal of Analytical Chemistry. Vol. 9, No. 1, 2021, pp. 26-31. doi: 10.11648/j.sjac.20210901.13

Received: February 10, 2021; Accepted: March 1, 2021; Published: March 30, 2021

\begin{abstract}
Algae samples from Dakar coast (Senegal) and Galician Rias (Spain) were analyzed by cold vapor atomic absorption spectrometry (CV-AAS) to assess the bioaccumulation of mercury in the two aquatic systems. In this work, the contents of inorganic mercury and total mercury were determined. Simplified analytical procedures (microwave digestion and ultrasonic assisted extraction) were used for sample preparation. A reference material (BCR-60) was used to validate the analytical procedures used for sample preparation. The results of the analysis show that the total mercury contents found in algae samples from the Galician Rias are relatively similar to those found in algae samples from the Dakar coast. However, the inorganic mercury content of the algae from Pontevedra Ria was considerably higher than that found in the algae samples from Vigo Ria. The distribution was observed for inorganic mercury and total mercury, indicating that inorganic mercury is the major mercury species that bioaccumulates in marine algae. The inorganic mercury contents were always approximately equal to those of total mercury in the algae samples and a satisfactory correlation $(p<0.0001 ; r=0.9997)$ was obtained between them. Finally, the ANOVA analysis indicates that no significant difference $(F=0.165 ; p=0.809)$ was found between the algae of the two aquatic systems (Dakar coast and Galician Rias).
\end{abstract}

Keywords: Algae, Mercury, Bioaccumulation, Dakar Coast, Galician Rias

\section{Introduction}

During the last decades, mercury has been widely used in various processes. This phenomenon combined with other anthropogenic activities has caused significant emissions of this substance into the environment [1]. In aquatic systems, mercury generally accumulates in surface sediments by adsorption or precipitation. The sedimentary compartment is considered a fundamental element of the biogeochemical cycle of mercury that can be transformed and mobilized to the water column or bioaccumulated in biota [2].

In Senegal, the industrial and domestic waters of the city of Dakar are poured directly into the aquatic environment without any prior treatment, thus threatening the health of the population [3-5]. Numerous scientific studies have been conducted in the area but have not dealt with the subject of mercury [6, 7]. Fishery products from the Senegalese coasts, that of the Dakar region, are overexploited and marketed locally, in the absence of analyses of mercury and its derivatives [8]. In contrast, in African countries, such as Ghana, the presence of mercury has been assessed in some species of fish and environmental samples [9-13].

In Spain, the Galician Rias (Northwest Atlantic), are generally influenced by anthropogenic contamination generated by various activities such as, industry, port facilities, aquaculture, urban agglomerations, among others. These areas constitute estuaries, with residual circulation of fresh and saltwaters, resulting in a large accumulation of metals in the sediments [14]. However, mercury research in sediments and biota in Galician rivers is rare, $[15,16]$. Similarly, the distribution of inorganic mercury has never 
been studied.

The main objective of this work is to evaluate the contamination of inorganic and total mercury in marine algae from two different geographical areas limited by the Atlantic Ocean: two Galician Rias (Vigo and Pontevedra) and the coast of Dakar.

\section{Experimental}

\subsection{Instrumentation and Reagents}

Instrumentation and reagents Inorganic and total mercury determination was carried out by Cold Vapor Atomic Absorption Spectrometry (CV-AAS) using a NIC-RA-3000 System at $253.7 \mathrm{~nm}$ and $\mathrm{SnCl}_{2}$ as reducing agent. A high intensity ultrasonic processor (Sonopuls HD 2200) equipped with titanium probes was used as ultrasound energy source. A domestic microwave oven (Moulinex, $900 \mathrm{~W}$ power) was used for microwave heating. An ultraviolet digestion system was used to transform organomercury species into $\mathrm{Hg}$ (II). A $45 \mathrm{~mL}$ capacity Parr reactor (model 4782) was used for acid digestion of all analyzed samples. A ball-mill (Retsh, model S100) equipped with a $250 \mathrm{~mL}$ capacity agate cup was used for grinding the solid samples. A nylon sieve $(70 \mu \mathrm{m})$ was used to homogenize the particle size of the samples.

All reagents employed were of analytical reagent grade and all of them were supplied by Merck. High purity water (Millipore Milli-Q System) was used throughout. The stock solution of mercury $(1000 \mu \mathrm{g} / \mathrm{mL})\left[\mathrm{Hg}\left(\mathrm{NO}_{3}\right)_{2}\right.$ in $\left.\left.2 \mathrm{M} \mathrm{HNO}_{3}\right)\right]$ was also acquired from Merck. An aquatic plant (BCR-60) from the Community Bureau of Reference (BCR) were used to validate the analytical methodology employed in this work. Statistical analysis was performed using the IBMSPSS Statistic (version 19) program.

\subsection{Sample Collection and Preparation}

Algae samples analyzed in this work were collected from the coast of Dakar (Senegal) and the Rias of Galicia (Spain). The maps in figure 1 show the two study areas as well as the location of the corresponding sampling points. For this study, six representative points of the Dakar coast (Figure 1a) were selected. The Dakar coast was selected for its relatively high urban and industrial activities. The algae from Galicia were collected in different sampling points in the Rias de Vigo and Pontevedra. On the one hand, the Ria de Vigo is affected by significant anthropogenic inputs mainly associated with metallurgical industries and an important commercial port. On the other hand, the Ria de Pontevedra is mainly affected by industrial discharges from a chlorine-alkali industry and a pulp mill there. The sampling points of Vigo and Pontevedra Rias (Figure 1b) were selected taking into account accessibility as well as point sources of pollution located in the two areas.

All marine algae were collected and placed into plastic bags at $4{ }^{\circ} \mathrm{C}$ until laboratory processing. In laboratory, algae samples are dried in an oven maintained at a temperature of $40^{\circ} \mathrm{C}$ and that of ventilation, ambient. After drying, the samples are crushed and sieved to obtain particles smaller than $70 \mu \mathrm{m}$. Finally, the homogenized samples were stored in polyethylene bottles and then stored in a desiccator until analysis.

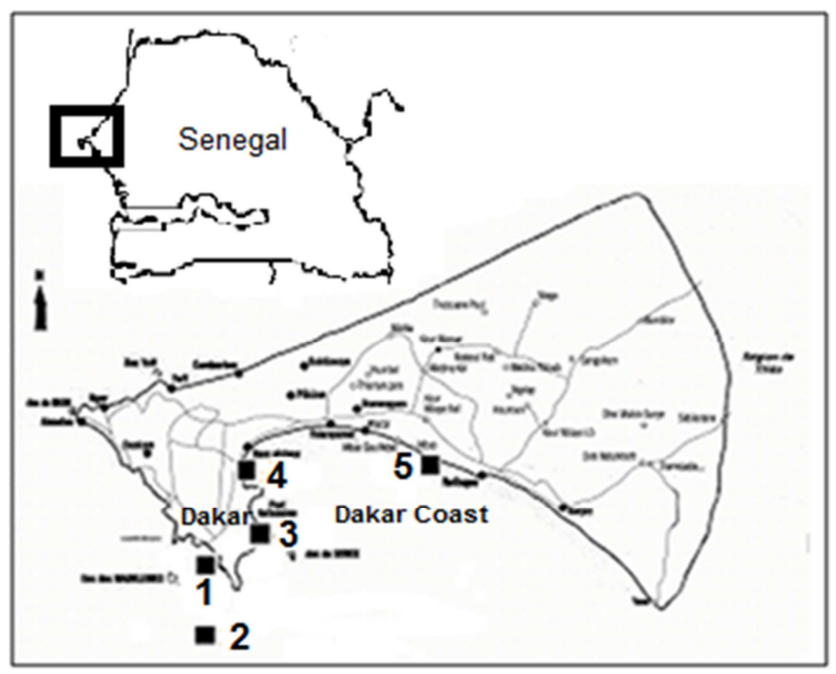

a

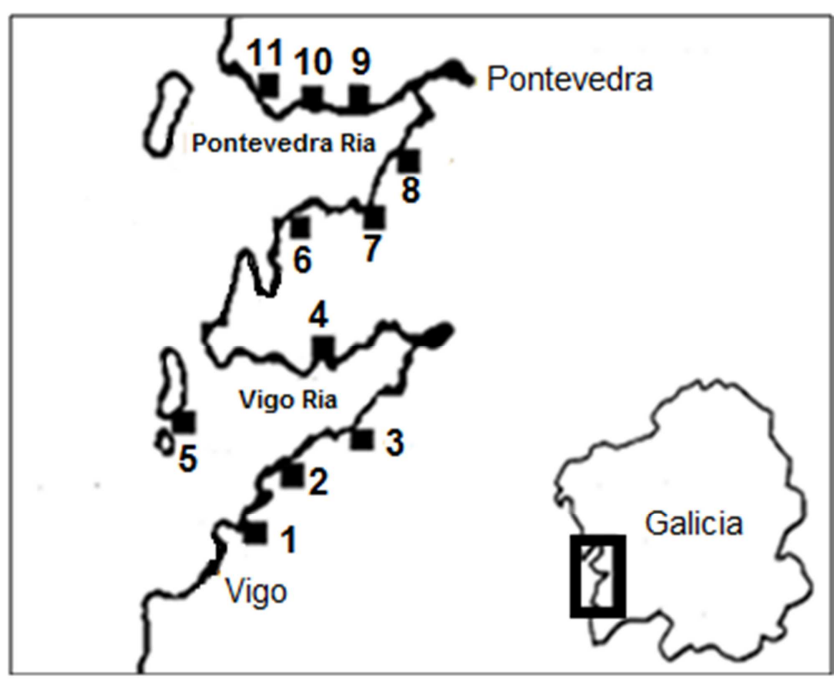

b

Figure 1. Location of sampling points in the Dakar coast (a) and Galician Rias (b).

\subsection{Chemical Analysis}

Total mercury was determined in algae according to the method described in the laboratory [17]. For this, $0.15 \mathrm{~g}$ of treated algae sample is placed with $4 \mathrm{~mL}$ of concentrated nitric acid (65\%) in a PTFE tube of the reactor, stirred under pressure. The container is then closed and heated in the microwave oven for $2 \mathrm{~min}$, at a power of $450 \mathrm{~W}$. After cooling, $1 \mathrm{~mL}$ of hydrogen peroxide $(30 \%)$ is added, to complete the decomposition of the sample. The solution is again heated for $1 \mathrm{~min}$ at the same power $(450 \mathrm{~W})$, then transferred quantitatively to a $25 \mathrm{~mL}$ flask and finally diluted volume to volume with ultra-pure water. The final solution is stored at $4^{\circ} \mathrm{C}$ in a hermetically sealed polyethylene bottle until analysis by Cold Vapor Atomic Absorption Spectrometry (CV-AAS) 
Extraction of inorganic mercury in algae samples is performed using a high-intensity ultrasonic device, equipped with a titanium probe [18]. For this about $0.2 \mathrm{~g}$ of prepared dry algae, is placed in a glass tube with $15 \mathrm{~mL}$ of a mixture of nitric acid $(30 \% \mathrm{w} / \mathrm{v})$ and hydrochloric acid $(2.5 \% \mathrm{w} / \mathrm{v})$ were added. Then, the mixture is sonicated for 3 minutes under an amplitude of $25 \%$. After sonication, the supernatant liquid is separated from the solid phase by centrifugation for $6 \mathrm{~min}$ at a speed of $1200 \mathrm{rpm}$. This solution is subjected to UV radiation for an optimum time of 15 minutes. The inorganic mercury ion of methylmercury is reduced to the metal mercury by using chloride $\left(\mathrm{SnCl}_{2}\right)$. This solution was quantitatively transferred into a $25 \mathrm{~mL}$ volumetric flask and diluted to volume with ultrapure water, before quantitative analysis by Cold Vapor Atomic Absorption Spectrometry (CV-AAS). The blank is prepared in the same way but without adding the sample.

\section{Results and Discussion}

\subsection{Analysis of Marine Algae}

The reliability of procedure for the determination of inorganic mercury in algae samples using the BCR-60 obtained by the Community Reference Bureau (BCR) of the European Union. The results agree very well with the certified values (Table 1). The statistical comparison of the experimental and certified values (t-test, the confidence level of $95 \%$ ), indicates that no significant differences were found testifying to the quality of the results reported in this paper. The reference test value $(95 \%)$ for a series of four measurements $(n=4)$ is equal to 3.18 [19].

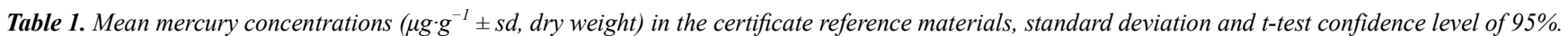

\begin{tabular}{|c|c|c|c|c|}
\hline Certified reference material & Certified & Measured (n=4) & D. S. R (\%) & t-test \\
\hline BCR-60 & $0.34 \pm 0.04$ & $0.3302 \pm 0.0100$ & 4 & 1.892 \\
\hline
\end{tabular}

The results obtained in algae sample from Dakar coast and Galician Rias are shown in Tables 2 and 3, respectively. All the values are expressed in $\mu \mathrm{g} / \mathrm{g}$ (dry weight) and they are given as mean of four separated determinations and their standard deviation. In the Dakar coast, the inorganic mercury in the algae samples were found between 0.0115 and 0.0250 $\mu \mathrm{g} / \mathrm{g}$ dry weight (Table 2). The locality of Cap Manuel indicates the lowest values, while the port of Dakar has the higher values of mercury. The poisoning is also more proven in the species Ulva lactuca. Samples were taken from two surveys conducted within one year. During this period, inorganic mercury concentrations are substantially constant. Thus, the algae, of the Dakar coast, do not accumulate this type of pollutant.

Table 2. Inorganic mercury ( $\mu \mathrm{g} / \mathrm{g} \pm \mathrm{sd}$, dry weight) in algae samples from Dakar coast.

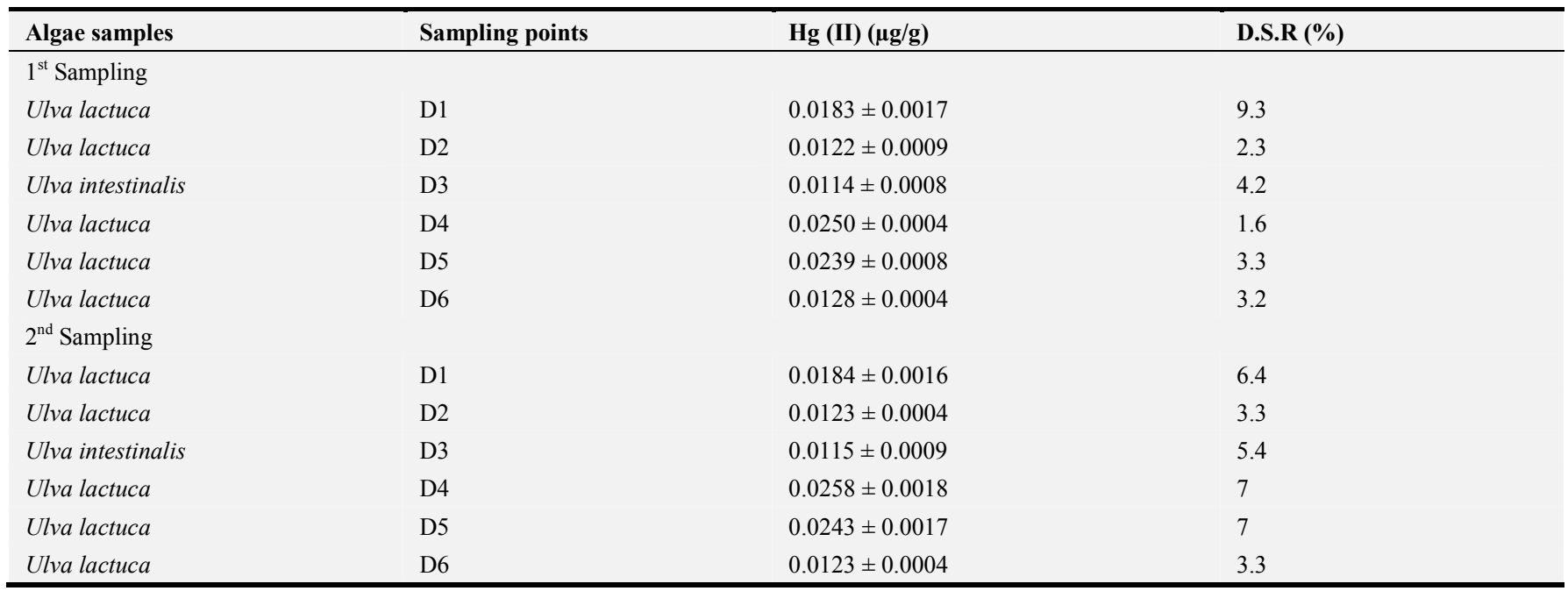

Inorganic mercury levels, found in algae samples from Galician Rias, range from 0.0103 to $0.0387 \mu \mathrm{g} / \mathrm{g}$ d.w. (Table 3). The lowest concentrations are noted at point G7, of Pontevedra, with the species Ulva intestinalis. The highest content is found at point G8 with the species Ulva lactuca. Vigo samples are also less contaminated than Pontevedra. Much higher levels, ranging from 0.02 to $2.1 \mu \mathrm{g} / \mathrm{g}$ dry weight, were found in aquatic plants in Aveiro Bay (Portugal) [20]. Similarly, in various species of algae in Guaymas Bay
(Mexico), mercury concentrations are in the range 0.058 to $0.134 \mu \mathrm{g} / \mathrm{g}$ dry weight [21]. This variability of the results can be attributed to the cell wall of macroalgae, which is considered as an important site for the complexation of metal cations [22]. For this reason, algae can be considered good bioindicators of metal contamination. To this end, several studies using different species of algae (Ulva and Enteromorpha) have been developed [23, 24]. 
Table 3. Inorganic mercury ( $\mu \mathrm{g} / \mathrm{g} \pm \mathrm{s} d$, dry weight) in algae samples from Galician Rias.

\begin{tabular}{|c|c|c|c|}
\hline Algae samples & Sampling points & Hg (II) $(\mu \mathrm{g} / \mathrm{g})$ & D.S.R (\%) \\
\hline \multicolumn{4}{|l|}{ Vigo Ria } \\
\hline Ulva lactuca & G1 & $0.0108 \pm 0.0006$ & 5.6 \\
\hline Ulva lactuca & $\mathrm{G} 2$ & $0.0153 \pm 0.0004$ & 2.6 \\
\hline Ulva lactuca & G3 & $0.0205 \pm 0.0004$ & 2 \\
\hline Ulva lactuca & G4 & $0.0204 \pm 0.0004$ & 3.8 \\
\hline Ulva lactuca & G5 & $0.0107 \pm 0.0005$ & 3.7 \\
\hline \multicolumn{4}{|l|}{ Pontevedra Ria } \\
\hline Ulva intestinalis & G6 & $0.0122 \pm 0.0007$ & 3.9 \\
\hline Ulva intestinalis & G7 & $0.0103 \pm 0.0004$ & 2.9 \\
\hline Ulva lactuca & G8 & $0.0387 \pm 0.0007$ & 1.8 \\
\hline Ulva lactuca & G9 & $0.0228 \pm 0.0005$ & 2.2 \\
\hline Ulva intestinalis & G10 & $0.0117 \pm 0.0004$ & 3.4 \\
\hline Ulva lactuca & G11 & $0.0109 \pm 0.0006$ & 5.5 \\
\hline
\end{tabular}
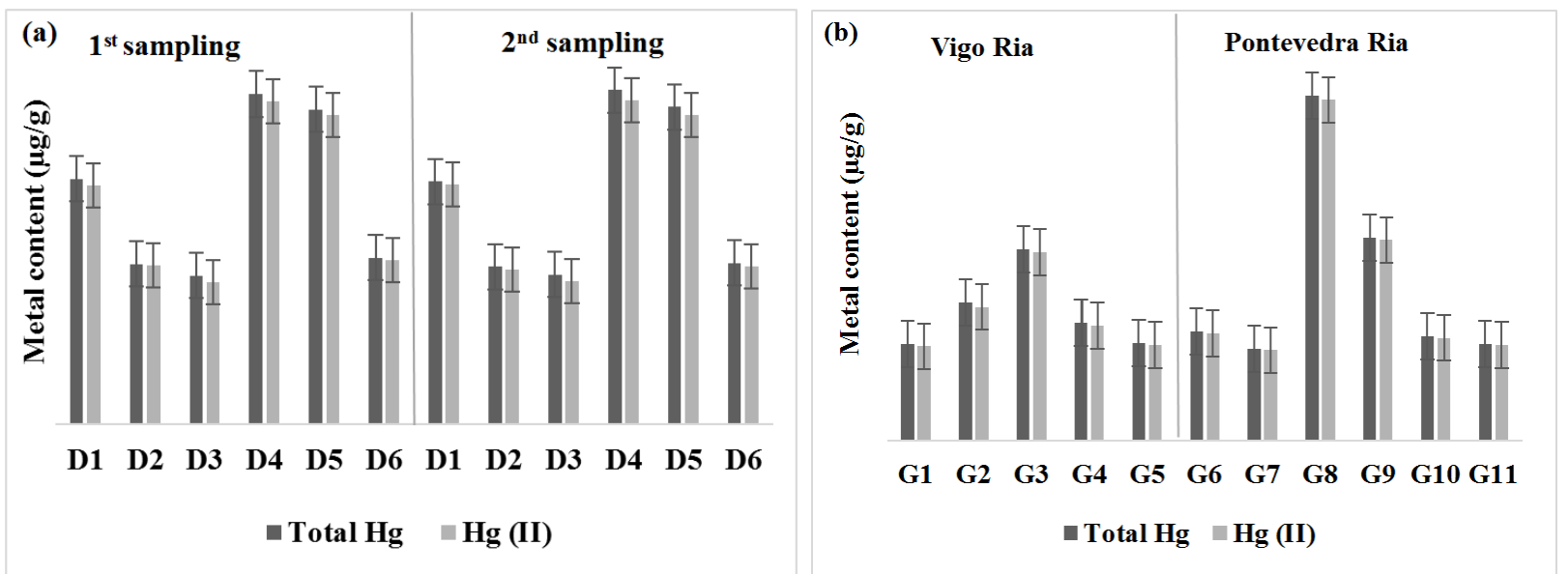

Figure 2. Distribution of inorganic and total mercury in marine algae from Dakar coast (a) and Galician Rias (Vigo and Pontevedra) (b).

The results of Figure 2 (a, b) make it possible to affirm that in algae samples, the majority species is the inorganic mercury with percentages of recovery varying between $96.8 \%$ and $99.1 \%$ of inorganic mercury/mercury total. Other authors, Dombaiova et al., 2005, quantified the levels of total mercury and methylmercury in plants (Corylys avellana L, Quercus polycarpa Schur et Achillea milefolium L) from different areas of Slovenia. In all samples analysed, the highest methylmercury content found was $0.00323 \mu \mathrm{g} / \mathrm{g}$, indicating a very low percentage of methylmercury relative to total mercury [25]. Authors such as Coelho et al., 2005, quantified levels of mercury and organic mercury in algae (Enteromorpha, Fucus and Gracilaria) from the coastal lagoon of Ria Aveiro (Portugal) [20]. The percentages of methylmercury content relative to total mercury do not exceed $15 \%$. The percentages obtained are higher than the values found in the algae analyzed in this work where the percentages of methylmercury relative to inorganic mercury vary between 0.9 and $3.2 \%$.

\subsection{Statistical Analysis}

A correlation analysis between the content of inorganic and total mercury in all marine algae analyzed in the aquatic ecosystem of Dakar has been established. A significant positive correlation between the two variables was found, as shown in Figure 3.

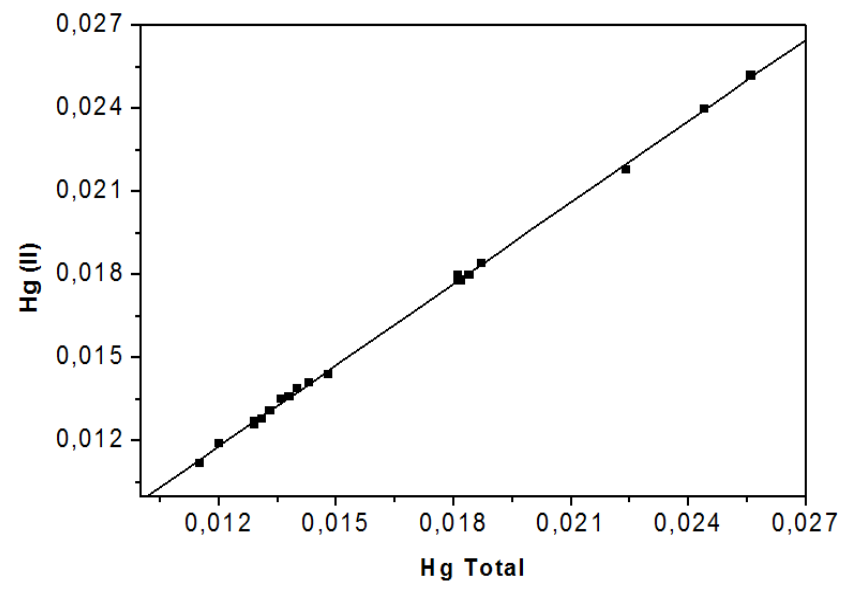

Figure 3. Correlation between inorganic mercury and total mercury in algae samples,

A good regression $(\mathrm{p}<0.0001)$ was obtained with a satisfactory correlation coefficient $(\mathrm{r}=0.9997)$. The ordinate at the origin of the regression is positive and practically equal to unity (0.982) and the slope is practically zero (0.00003), which indicates that the inorganic mercury is still substantially equal to the total mercury in the seaweed, then 
an increase in mercury in the algae causes an increase in bioaccumulation in the biota. Finally, ANOVA analysis indicates that no significant differences $(\mathrm{F}=0.165 ; \mathrm{p}=0.809)$ were found among the algae samples collected at different sampling points of the Galician Rias (Vigo and Pontevedra) and Dakar coast, and neither between the two compared aquatic systems, Galicia and Dakar $(\mathrm{F}=0.124 ; \mathrm{p}=0.716)$.

\section{Conclusion}

The objective of this study was to evaluate the bioaccumulation of inorganic mercury and total mercury in algae samples by Cold Vapor Atomic Absorption Spectrometry (CV-AAS). The samples of algae used come from the coast of Dakar (Senegal) and Galician Rias (Spain). The analysis results show that the levels found in algae samples from Galician Rias are relatively similary to those found in algae samples from the Dakar coast. Inorganic mercury is the most abundant species of mercury in all algae analyzed, with percentages of inorganic mercury to total mercury ranging from 96.8 to $99.1 \%$. A satisfactory correlation was obtained between inorganic mercury and total mercury. Finally, the ANOVA analysis indicates that no significant difference was found in algae samples studied between the two aquatic systems of the Dakar coast and the Galician Rias.

\section{References}

[1] Shi J. B., Carman C. M., Tang C. W. Y., Zhang G., Rudolf S. S., Dong X. (2007). Spatial and Temporal Variations of Mercury in Sediments from Victoria Harbour, Hong Kong. Mar. Pollut. Bull., 54, 464-488.

[2] Wiener J. G., Krabbenhoft D. P., Heinz G. H., Scheuhammer A. M. (2003). Ecotoxicology of Mercury. In: Handbook of Ecotoxicology, D. J. Hoffman et al (Eds.), CRC Press, pp. 409-463.

[3] Bloundi M. K., Duplay J., Quaranta G. (2009). Heavy metal contamination of coastal lagoon sediments by anthropogenic activities: the case of Nador (East Morocco). Environ. Geol., $56,833-843$.

[4] Geffard A., Amiard-Triquet C., Amiard J. C., Mouneyrac C. (2001). Temporal variations of metallothionein and metal concentrations in the digestive gland of oysters (Crassostrea gigas) from a clean and a metal-rich site, Biomarkers. 6, 91107.

[5] Žižek S., Horvat M., Gibičar D., Fajon V., Toman M. J. (2007). Bioaccumulation of mercury in benthic communities of a river ecosystem affected by mercury mining. Sci. Total Environ., 377, 407-415.

[6] Diagne I., Ndiaye M., Ndiaye B., Diop A., Thiom M. (2013). Evaluation de la contamination métallique des moules Mytilus galloprovincialis et des sédiments marins au niveau des côtes de la région de Dakar (Sénégal). Int. J. Biol. Chem. Sci., 7, 872-883.

[7] Ndiaye B., Ndiaye M., Diop A., Thiom M. (2011). Profile study of the marine sediment contamination in Dakar by copper, zinc and nickel. J. Sci. Technol., 9, 28-35.

[8] Ndiaye B., Ndiaye M., Pérez Cid B., Diop A., Diagne I., Cissé D., Dione C. T., Hane M. (2020). Total Mercury and Methylmercury Distribution in Paguellus bellottii Fish from Soumbedioune Beach, Senegal. Earthline J. Chem. Sci., 4 (1), 67-76.

[9] Kwaansa-Ansah E., Agorku S., Nriagu J. (2011). Levels of Total Mercury in Different Fish Species and Sediments from the Upper Volta Basin at Yeji in Ghana. Bull. Environ. Contam. Toxicol., 86, 406-409.

[10] Oppong S., Voegborlo R., Agorku S., Adimado A. (2010). Total Mercury in Fish, Sediments and Soil from the River Pra Basin, Southwestern Ghana. Bull. Environ. Contam. Toxicol., 85, 324-329.

[11] Voegborlo R. B., Adimado A. A., Ephraim J. H. (2007). Total Mercury Distribution in Different Tissues of Frigate Tuna (Auxis thazard thazard) from the Atlantic Coastal Waters of Ghana, Gulf of Guinea. Environ. Monit. Assess., 132, 503508 .

[12] Cisse D., Ndiaye B., Ndiaye M., Diagne I., Dione C. T., Hanne M., Diop A. (2020). Comparative study of physicochemical parameters of wastewater discharged at the beaches of the Dakar Coast. Afr. J. Environ. Sci. Technol., 14 (2), 64-69.

[13] Ndiaye B., Ndiaye M., Pérez Cid B., Diop A., Diagne I., Cissé D., Dione C. T., Hanne M. (2020). Trace metals in mussels Mytilus galloprovincialis from Dakar Coast (Senegal). Am. J. Anal. Chem., 11, 137-145. https://doi.org/10.4236/ajac.2020.113011

[14] Prego R., Cobelo-García A. (2003). Twentieth century overview of heavy metals in the Galician Rias (NW Iberian Peninsula). Environ. Pollut., 121, 425-452.

[15] Beiras R., Fernández N., González J. J., Besada V., Schultze F. (2002). Mercury concentrations in seawater, sediments and wild mussels from the coast of Galicia (NW Spain). Mar. Pollut. Bull., 44, 340-349.

[16] Canário J., Prego R., Vale C., Branco V. (2007). Distribution of Mercury and Monomethyl mercury in Sediments of Vigo Ria, NW Iberian Peninsula. Water Air Soil Pollut., 182, 21-29.

[17] Perez-Cid B., Silva C., Boia C. (2002). Application of Leaching Tests for the Assessment of Available Heavy Metals from Domestic and Industrial Sludges. Int. J. Environ. Anal. Chem., 82, 721-732.

[18] Ndiaye B., Ndiaye M., Diop A., Pérez-Cid B. (2015). Determination of methyl mercury in biological samples from Dakar coast using CV-AAS and a simple ultrasound method. Res. J. Chem. Environ. 19 (4), 1-7.

[19] Taylor John K. (1987). Quality Assurance of Chemical Measurements, U.S.A., Lewis Publishers, 328.

[20] Coelho J. P., Pereira M. E., Duarte A., Pardal M. A. (2005). Macroalgae response to a mercury contamination gradient in a temperate coastal lagoon (Ria de Aveiro, Portugal). Estuar. Coast. Shelf Sci., 65, 492-500.

[21] Green-Ruiz C., Ruelas-Inzunza J., Páez-Osuna F. (2005). Mercury in surface sediments and benthic organisms from Guaymas Bay, east coast of the Gulf of California. Environ. Geochem. Health, 27, 321-329. 
[22] Vasconcelos M. T. S. D., Leal M. F. C. (2001). Seasonal variability in the kinetics of $\mathrm{Cu}, \mathrm{Pb}, \mathrm{Cd}$ and $\mathrm{Hg}$ accumulation by macroalgae. Mar. Chem., 74, 65-85.

[23] Astorga-España S., Calisto-Ulloa N. C., Guerrero S. (2008). Baseline Concentrations of Trace Metals in Macroalgae from the Strait of Magellan, Chile. Bull. Environ. Contam. Toxicol., $80,97-101$.
[24] Costa S., Crespo D., Henriques Bruno M. G., Pereira E., Duarte A. C., Pardal M. A. (2011). Kinetics of Mercury Accumulation and Its Effects on Ulva lactuca Growth Rate at Two Salinities and Exposure Conditions. Water Air Soil Pollut., 217, 689-699.

[25] Dombaiova R. (2005). Mercury and methylmercury in plants from differently contaminated sites in Slovakia. Plant Soil Environ., 51, 456-463. 